\title{
DIE ROL VAN DIE GEMEENSKAPSVERPLEEGKUNDIGE IN GEESTESGESONDHEID
}

\author{
LOUISE OLIVIER (B. Cur(UP) DVO (UP)) \\ ORGANISEERDER VAN VERPLEEGDIENSTE - \\ DEPARTEMENT GESONDHEID, WELSYN EN PENSIOENE
}

\begin{abstract}
SUMMARY
Mental health is an umbrella-like concept encompassing the psychological, emotional and social equilibrium of an individual. Today we are confronted with an ever increasing incidence of mental illness. The individual is unable to adapt and his reactions are unacceptable, inappropriate and inadequate.

The community nurse plays a very important role in the prevention of mental illness and the promotion of mental health. The community nurse comes into contact with many people in the community such as the infants, school children, mothers as well as the aged. She is in the position to identify the earliest signs of mental illness and she is also in the ideal position to promote mental health. She plays a role at the primary, secondary and tertiary levels of prevention and must therefore be adequately trained and prepared for this very important function.
\end{abstract}

\section{INLEIDING}

Die Wêreldgesondheidsorganisasie psigiese en sosiale welsyn van die individu. Om geestesgesond te wees is net so belangrik as om fisies gesond te wees en dit is uiters belangrik om te besef dat ons nie die fisiese en psigiese gesondheid van mekaar kan skei nie - die een het 'n invloed op die ander.

Die meeste mense beskou geestessiekte as iets wat nie met hulle of hul gesinne kan gebeur nie.

\section{Die omvang van die probleem:}

Die statistiek van die Departement Gesondheid, Welsyn en Pensioene is 'n aanduiding van die aantal pasiënte wat in departementele psigiatriese hospitale behandeling ontvang het. Die syfers vir opnames in departementele psigiatriese hospitale word in Tabel 1 aangedui en statistiek oor gemeenskapspsigiatriese dienste in Tabel 2.
Tabel 1: Opnames in psigiatriese hospitale van die Departement Gesondheid, Welsyn en Pensioene (1978-1980)

$\begin{array}{lrrr} & \mathbf{1 9 7 8} & \mathbf{1 9 7 9} & \mathbf{1 9 8 0} \\ \text { Eerste opnames } & 16268 & 15886 & 16809 \\ \text { Heropnames } & 9358 & 9557 & 9880 \\ \text { Totaal } & 25626 & 25443 & 26689\end{array}$

Groot getalle pasiënte word ook deur privaatgeneeshere en by provinsiale hospitale behandel.

Dan kan daar ook met sekerheid aangeneem word dat 'n groot persentasie van die bevolking hulp nodig het maar nog geen behandeling ontvang het nie.

In die pers kan daar daagliks gelees word van die publiek se kommer oor die

\section{Tabel 2: Gemeenskapspsigiatriese dienste van die Departement Gesondheid, Welsyn en Pensioene (1978-1980)}

\begin{tabular}{lrrr} 
& $\mathbf{1 9 7 8}$ & $\mathbf{1 9 7 9}$ & \multicolumn{1}{c}{$\mathbf{1 9 8 0}$} \\
Aantal kliniekbesoeke & 696303 & 399329 & 467892 \\
Aantal tuisbesoeke & 40037 & 37870 & 39951
\end{tabular}

omvang van geestesongesteldheid en dit is verblydend dat die Geestesgesondheidstigting onlangs van stapel gestuur is met Regter M.J. Steyn as die erepresident.

Die doel van die stigting is hoofsaaklik om die publiek op te voed en by geestesgesondheid, die insameling van fondse vir geestesgesondheidsverenigings en die beskikbaarstelling van beurse vir die opleiding van professionele persone te betrek.

Dit is uiters noodsaaklik dat elkeen verantwoordelikheid vir sy eie geestesgesondheid aanvaar. In die moderne wêreld is ons daagliks, weens al die spanning waaraan ons blootgestel word, besig om te stry om geestesgesond te bly. In die kompeterende lewe van vandag ondervind ons spanning in ons gesinne, skole, universiteite, werksituasies en selfs nadat ons afgetree het. 


\section{GEESTESGESONDHEID}

Vir elkeen van ons en veral vir die verpleegkundige in die gemeenskap is dit dus noodsaaklik om te weet wat geestesgesondheid is.

In die literatuur is daar verskillende sienings van wat 'n geestesgesonde persoon is, maar in wese kan dit hoofsaaklik beskou word in terme van die drie verhoudingsvlakke, naamlik die verhouding met die self; met ander en met die omgewing. Die geestesgesonde persoon is iemand wat oor selfkennis beskik, wat van homself hou en homself aanvaar en respekteer. Hy erken sy beperkinge en probeer om hom te verbeter. Hy respekteer ander en kan positiewe verhoudings aanknoop en in stand hou. Hy aanvaar ook die verantwoordelikheid om skadelike verhoudings te beëindig en hy kommunikeer direk op verbale en nie-verbale wyse. In sy verhouding met sy omgewing is die geestesgesonde persoon in staat om sy omgewing te organiseer en om beheer daaroor uit te oefen en kan hy hom ook by veranderinge aanpas. Ons moet egter versigtig wees en nie by die afwesigheid van een van die kriteria die persoon as geestesiek beskou nie, maar aanneem dat dit op 'n area van onbekwaamheid dui waarop verbeter kan word.

\section{DIE GEMEENSKAPSVERPLEEG- KUNDIGE}

Die gemeenskapsverpleegkundige is die persoon wat met die publiek te doen kry van die pasgeborene tot die bejaarde en sy kan 'n baie belangrike rol in die voorkoming van geestesongesteldheid asook die vroeë identifikasie van verdagte simptome speel.

Dit is belangrik dat die gemeenskapsverpleegkundige sal weet wat die oorsake van geestesongesteldheid is, want dit is binne hierdie raamwerk dat sy haar belangrike voorkomingstaak vervul. Dit is dus nodig dat ons slegs kortliks daarna sal kyk.

\section{Oorsake van geestesongesteld- heid}

Genetiese faktore: Verskeie psigiatriese ongesteldhede word toegeskryf aan eienskappe wat tydens bevrugting oorgedra word. 'n Paar voorbeelde van geneties oordraagbare toestande is manies-depressiewe psigose; skisofrenie, Huntingtonchorea, epilepsie en geestesvertraagdheid.

Chemiese faktore: Enige chemiese bestanddeel wat die funksionering van die brein beïnvloed, kan ook geestesongesteldheid veroorsaak. 'n Paar voorbeelde word kortliks genoem.
- 'n Gebrek aan suurstof verswak die oordeelsvermoë.

- Die brein is baie sensitief vir 'n abnormale konsentrasie van glukose. Hiperglukemie kan vergeetagtigheid, prikkelbaarheid en buierigheid veroorsaak, terwyl 'n erge hipoglukemie onherstelbare breinskade kan veroorsaak.

- Gebrekkige kilojoule-inname lei tot algemene apatie wat 'n verlaagde psigologiese stimulasie kan veroorsaak wat op sy beurt weer tot geestesvertraagdheid aanleiding kan gee.

- Die tireoïedhormone speel 'n belangrike rol in breinfunksie aangesien 'n gebrekkige afskeiding by die pasgeborene aanleiding gee tot geestesvertraagdheid, en by die volwassene verwardheid en psigotiese toestande veroorsaak.

- 'n Langdurige oormaat van AKTH gee aanleiding tot 'n toestand van euforie of 'n tipiese depressiewe toestand met rusteloosheid, depressie en hallusinasies.

- Daar is ook chemiese bestanddele soos amfetamien, L.S.D. Cannabis en alkohol wat sekere emosionele en gedragsveranderinge teweegbring.

Organiese toestande: Fisiese toestande soos breingewasse, traumatiese breinbeserings en sifilis kan tot geestesongesteldheid lei.

Psigogeniese faktore: Dit behels hoofsaaklik die persoon se subjektiewe en emosionele gevoelens oor homself en sluit in gevoelens soos eiewaarde, sekuriteit, welsyn, selfverwesenliking, skuldgevoelens en minderwaardigheid.

Wanneer 'n persoon situasies moet hanteer wat hom negatief teenoor homself instel, maak hy van verdedigingsmeganismes gebruik.

Indien hierdie negatiewe gevoelens voortduur, veroorsaak dit al hoe meer angs met die gevolg dat die individu al hoe meer van noukeurige verdedigingsmeganismes gebruik maak wat later ook nie meer slaag nie.

Ouderdomsverwante faktore: Daar is sekere periodes in die lewensiklus van die individu wanneer hy emosioneel meer kwesbaar is as gewoonlik, soos die adolessente jare, oorgangsjare en die tydperk van bejaardheid.

Interpersoonlike faktore: Die vroeë verhoudings in die gesin, veral met die ouers, beïnvloed die individu se vermoë om die probleme van die volwasse lewe baas te raak.
Kulturele faktore: Verskeie waardes en idees word deur sy kultuur by die individu ingeprent en hy moet sy lewe lank daarby aanpas. Daar word selfs geslagswaardes aan kleure, meubels, beroep en stokperdjies gekoppel en rolverwarring tussen die geslagte speel 'n belangrike rol in die geestesgesondheid van die betrokke persone.

\section{Vroeë tekens en simptome}

Dit is nie slegs vir die gemeenskapsverpleegkundige belangrik om die oorsake van geestesongesteldheid te ken nie, maar sy moet ook die vroeë tekens en simptome kan herken.

Daar is verskeie waarskuwingstekens wat of fisies of psigies kan wees.

Fisiese simptome kan insluit borspyne, hartkloppings, diaree, slegte spysvertering, hoofpyne, slaaploosheid, aanhoudende moegheid asook verskeie ander simptome wat eintlik op geestesongesteldheid dui.

Op die psigiese vlak is daar ook simptome wat as waarskuwing kan dien, soos 'n onvermoë om te konsentreer, vergeetagtigheid, gebrek aan wilskrag, impulsiewe gedrag, onvermoë om te ontspan, ongeduld, onverdraagsaamheid, gevoelens van jaloesie, selfbejammering, frustrasie, wanhoop, angs, vyandigheid, skuld, wantroue, misnoeë, eensaamheid en afhanklikheid. Afhanklikheid van alkohol en geneesmiddels asook 'n geneigdheid tot misdaad kan tekens van geestesongesteldheid wees.

\section{Voorkoming van geestesonge- steldheid}

Die belangrikste rol van die verpleegkundige in die gemeenskap is om geestesongesteldheid te voorkom en om geestesgesondheid te bevorder.

Voorkoming van geestesongesteldheid is baie kompleks en vind op drie vlakke plaas, naamlik primêre, sekondêre en tersiêre voorkoming.

Primêre voorkoming is daarop gerig om geestesongesteldheid te verminder en te voorkom en is die belangrikste vlak van voorkoming. Tydens die verskillende lewensfases van elke individu kan verskeie faktore hom sodanig beinvloed dat die een of ander vorm van geestesongesteldheid ontstaan. Tydens al hierdie fases kan die gemeenskapsverpleegkundige 'n besondere rol speel.

Deur middel van gesinsbeplanning kan ongewenste swangerskappe voorkom word en met goeie voorgeboortesorg kan daar in 'n groot mate verseker word dat 'n normale baba sonder enige komplikasies gebore word.

Die nageboorteperiode sluit die individu se hele lewensloop in en dit word gekenmerk deur verskeie lewenskrisisse 
wat beskou word as emosie-belaaide, onverwagte en dreigende gebeurtenisse waar die reeds bekende metodes van probleemoplossing nie werk nie. Rolveranderinge wat krisisse kan veroorsaak is geboortes, skool, adolessensie, skoolverlating, huwelik, swangerskap, die geboorte van kinders asook ouderdom en aftrede.

Krisisse kan byvoorbeeld ontstaan as 'n geliefde afsterf, as daar van werk of woonplek verander word, as die persoon se selfbeeld geraak word, soos wanneer sy gesondheid verswak of hy 'n ledemaat of sy gesig of gehoor verloor. Persone wat weens swak gesondheid of omrede van die een of ander chirurgie in die hospitaal is, en selfs die familielede van die pasiënt is hoërisikogevalle.

Die verpleegkundige kan 'n belangrike rol speel in die werklike voorkoming van geestesongesteldheid. Sy moet haar gemeenskap ken en die hoërisikogevalle kan identifiseer.

Deur daar te wees, om te gee, vir die persoon te sorg en ander persone of organisasies tot hulpverlening te aktiveer, kan sy ' $n$ belangrike bydrae lewer.

Gedurende die krisis moet sy 'n klimaat skep waarin die pasiënt die vrymoedigheid het om sy probleem te bespreek, sy moet kan empatiseer en dan saam met die persoon die werklikheid van die krisis in die oë kyk. Dikwels word die fout gemaak om aan die persoon in ' $n$ krisis kalmeermiddels voor te skryf sonder om hom te help om die werklikheid te besef, met die gevolg dat baie van hierdie persone onbepaalde tye lank met die medikasie voortgaan.

Risikogroepe moet geïdentifiseer word en hiervolgens kan die verpleegkundige voorkomende voorligting en raad gee, soos in die gevalle van verwagteride moeders, persone wat aftreeouderdom nader, asook persone wat chirurgie moet ondergaan. Die verpleegkundige wat in die gemeenskap werk, kom daagliks met hierdie risikopersone in aanraking.

In 'n poging om geestesongesteldheid te voorkom, moet die gemeenskapsverpleegkundige in haar professionele beeld ook ' $n$ besorgdheid vir haar pasiënte aankweek en vaardighede ontwikkel om 'n omvattende diens aan haar pasiënte te lewer. Dit beteken 'n gedissiplineerde, maar tog 'n intieme en persoonlike kontak, waar die pasiënt die vrymoedigheid het om gevoelens van verlies, skuld, woede en vyandigheid te verwoord en waar die verpleegkundige ook die pasiënt kan help om hulp te aanvaar.

Die verpleegkundige speel ook ' $n$ belangrike rol in die voorkoming van geestesongesteldheid deur infeksies te help voorkom, deur die vroeë opsporing van fisiese siektes, vroeë identifikasie van moontlike fisiese en emosionele mishandeling van kinders, asook deur voorligting te verskaf ten einde 'n veilige omgewing tuis, by die werk en op die paaie te skep.

Dit is dus baie duidelik dat die verpleegkundige se rol op primêre vlak hoofsaaklik gemik is op gesondheidsvoorligting en die toepassing van emosionele eerstehulp. Dit is gerusstellend vir die gemeenskapsverpleegkundige om te besef dat elke persoon wat 'n krisis beleef nie noodwendig hulp nodig sal hê of geestesongesteld sal raak nie. Dit bemoeilik egter haar taak in die sin dat sy die vaardigheid moet ontwikkel om te identifiseer watter persone haar hulp nodig het.

Op die sekondêre vlak van voorkoming kan die gemeenskapsverpleegkundige ook 'n belangrike rol speel. Sekondêre voorkoming sluit in die vroeë herkenning en korttermynbehandeling van geestesongesteldheid.

Haar taak is dus om die pasiënt se ongesteldheid betyds te herken en hom na die regte instansie vir behandeling en opvolging te verwys.

Die pasiënte met sigbare simptome van geestesongesteldheid word gewoonlik deur die persone direk om hulle gedwing om behandeling te ondergaan. Baie persone se probleme word dikwels vir die eerste keer deur leke geïdentifiseer. Dit is die verpleegkundige se taak om die gemeenskap korrek in te lig sodat hulle op moontlike probleme bedag kan wees en hulle kan identifiseer. Eerstens is haar opvoedingstaak teenoor die gesinne onder haar sorg en tweedens teenoor die groter publiek deur groepe soos skoolkinders, vroueklubs en baie ander toe te spreek. Een van haar belangrikste funksies gedurende hierdie voorligtingsessies is om die stigma wat aan geestesongesteldheid kleef, te verwyder.

Daar is ' $n$ behoefte aan voorligting by professionele groepe soos geneeshere, regters, onderwysers en vele ander om hul houding te verander.

Dit is noodsaaklik dat die gemeenskapsverpleegkundige die vroegste tekens en simptome en die oorsake van geestesongesteldheid sal ken. Sy moet ook haar gemeenskapsbronne ken en sy moet 'n netwerk van ondersteuningstelsels opbou waarheen sy pasiënte kan verwys, hulp vir die gesinne, asook oplossings vir probleme wat geestesongesteldheid vererger, kan kry. Sy moet gevoelig wees vir die geestestoestand van elke pasiënt en moet nie slegs op fisiese simptome konsentreer nie.

Die tersiêre vlak van voorkoming sluit hoofsaaklik die rehabilitasie van die geestesongestelde persoon in. Rehabilitasie is die proses waardeur die persoon gehelp word om volgens sy eie kenmerke en vermoëns weer die maksimum aktiwiteit te bereik. Hierdie proses begin reeds tydens hospitalisasie en word in die gemeenskap voortgesit.

Dit is uiters noodsaaklik dat die pasiënt reeds gedurende die hospitalisasieprogram vir ontslag voorberei word, sodat hy sy beroep kan hervat en kontak met die buitelewe en familie behou. Die gemeenskapsverpleegkundige kan hier 'n belangrike rol speel deur die familie tydens hospitalisasie van die pasiënt te ondersteun en hulle ook vir die ontslag van die pasiënt voor te berei.

$\mathrm{Na}$ ontslag is haar rol hoofsaaklik om emosionele ondersteuning aan die familie te verskaf. Haar doel is om 'n terugval te voorkom en te verseker dat die pasiënt nie sosiaal geïsoleerd raak en hom van sy omgewing afsluit nie. Die pasiënte moet hulself versorg en ' $n$ aandeel hê in die instandhouding van hul omgewing en die handhawing van goeie interpersoonlike verhoudings waar almal hul eie gevoelens kan lug en bydra tot die vermindering van die stigma van geestesongesteldheid.

Die verpleegkundige speel ook 'n rol in die inskakeling van die pasiënt by sosiale groepe, moontlike beroepsgroepe en ander aktiwiteite en moet sy die beste maak van die pasiënt se huidige omgewing.

Die pasiënt moet aangemoedig word om sy geneesheer te besoek, klinieke by te woon en sy medikasie te neem. Die pasiënt word vir enige newe-effekte van die medikasie in die oog gehou.

\section{SLOT}

Dit wek kommer dat daar in die basiese opleiding nie genoeg aandag geskenk word aan die begrip geestesgesondheid nie. In die praktyk word verpleegstudente na psigiatriese hospitale vir die praktika ten opsigte van geestesgesondheid gestuur. Hier kry hulle egter slegs met die patologie te doen. Daar is dus 'n gebrek aan onderrig ten opsigte van die vaardighede en gesindhede wat vir werk in die gemeenskap benodig word.

Die Departement Gesondheid, Welsyn en Pensioene is in samewerking met verskeie ander opleidingsinstansies reeds besig om aandag aan hierdie saak te gee.

Departement Gesondheid, Welsyn en Pensioene. Jaar verslag 1980

2. Evans, F.M.C. The role of the nurse in community mental health. MacMillan. New York. 1968.

3. Gillis, L.S. Guidelines in psychiatry. David Philip. Cape Town. 1977.

4. Kreigh, H.Z., Perko, J. Psychiatric and mental health nursing: commitment to care and concem. Reston. Virginia. 1979.

5. Mereness, D.A., Taylor, C.M. Essentials of psychiatric nursing. C.V. Mosby. Saint Louis. 1978. 